\title{
Historical back training in most important points of neurosurgery
}

\author{
Nikolaos Syrmos ${ }^{1,2^{*}}$, Georgios Ampatzidis ${ }^{1,2}$, Anna Fachantidou ${ }^{1,2}$, loannis Mouratidis ${ }^{1,2}$, Chrsitos Syrmos ${ }^{1,2}$ \\ From $1^{\text {st }}$ International Congress on Neurobiology and Clinical Psychopharmacology and European \\ Psychiatric Association Conference on Treatment Guidance \\ Thessaloniki, Greece. 19-22 November 2009
}

\section{Background}

The History of Neurosurgery begins with the presence of human in the earth. Begins from the depths of History (reports in Bible, Greek Mythology), as a part with Surgery until the last half of the 20th Century. Archaeological discoveries of human skull's proved the affair that the first neurosurgical action is the trepanation of skull or trephination (Burr hole in the cranial capsule with hand working drill), from material proportional the epoch (stone - copper, iron, brass etc). Chronological probably before the presence of written proofs and the use of metals, perhaps and from this 10.000 b.C. This action perhaps presented as a cerebration (in dead), but also as therapeutic in alive. This is the first surgical technique that prepared the trepanation of skull or trephination and later the craniectomy.

\section{Materials and methods}

All of this came from discoveries of skulls and surgical instruments, and show that the first Neurosurgical interventions in Ancient Greece are reduced in the Minoan epoch (skull in the Aharnes), in the Mycenaean epoch (Mycenae's skull, Argos). The study of the History is under a methodology as follows:

A) Prehistoric period

B) Historic period

C) Invention of typography

D) Invention of photograph - cinema

E) Modern period

A more important steps in the History of Neurosurgery are the following:

- Prehistoric period

Prehistoric and primordial trephinations

- Embrionic period

${ }^{1}$ Department of Physical Education and Sports, Aristoteleian Univesity of Thessaloniki, Greece
Babylonian and Egyptian Medicine

- Greek - Roman and first Byzantine Period

The origins of Neurosurgery

a) Greek period - Greek Ancient (5th b.C. Century)

b) Roman Period

c) Early Byzantine period

- Arabic Period - Mediaeval Period

a) Arabic Medical School (750 - 1200 a.C.)

b) West-European Medieval (1000 - 1400 a.C.)

- Neurosurgery in 16 - 19th Century

a) 16th Century

Anatomic exploration

b) 17th Century

Origins of Neurology

c) 18th Century

Adventures Surgeons - Neurosurgeons

d) 19th Century

Anesthesia - Antisepsis - Cerebral localisation

- Advances in Surgical - Neurosurgical Techniques

- Historical Review in Anatomy - Physiology of Nervous System

The development of Neurosurgery is under investigations for Nervous System with improvement in Anatomy and Physiology:

- Brain

- White- Gray matter

- Cerebellum

- Ventrical System of the Brain

- Arterial - Venous system of the Brain

- Cerebral sulcus - Gyrus

- The creation of Speciality of Neurosurgery

\section{Results}

Neurosurgery as speciality it would have never become without progress in neuroanatomy, neurophysiology, neurology, radiology, angiography of C.N.S. and 
neuroimagine (CT, MRI etc), and the importation of technology in Medicine, with researchers to progress of Neuroscience.

The Neurosurgery in 1900-1940 represented by William Harvey Cushing (1869-1939) (the father of Neurosurgery) and Walter Edward Dandy (1886-1946), leaders in the History.

The History of Neuroimagine methods

The brain and the spinal cord under anatomic nature and place, for a lot of centuries kept well their secrets. Because existed difficulty of approach, as well as in localisation of the place of damage.

Surgery in C.N.S. is without probabilities and mistakes. The modern Neurosurgery began with the first imagine methods of $\mathrm{X}$ - rays in clinical practice.

The progress of imaging methods are with surgery of C.N.S., walking together as the diagnostic methods increases also surgical approaches are with bigger safety.

$\mathrm{X}$-ray of brain

Angiography of brain

CT of brain

MRI of brain

The History of Neurosurgery in Greece

Begins in the end of the 19th Century as a part of surgery and in the last decades of 20th Century as a new surgical speciality.

A' Period (1900-1920)

B' Period (1930-1950)

The speciality of Neurosurgery was established by V. Griponisiotis (1910-1993), Neurosurgeon and the first Professor of Neurosurgery after his election from Medical School of the A.U.TH. and director of the First Neurosurgical Clinic in 1966 in A.H.E.P.A. Hospital of Thessaloniki.

C' Period (The beginning of modern Neurosurgery)

\section{Conclusions}

The History of Microsurgery

Microsurgery in the Neurosurgical practice constitutes the point (perhaps the biggest), because gives opportunities for successful development.

The using of surgical microscope begins in 1960 and in 1965 by M. Gazi Yaşargil who came the first microsurgical intervention in the Brain (terminal by terminal anastomosis with superficial temporal cerebral artery with a rumus of medium cerebral artery).

The microsurgery involves revolution in the Neurosurgery, because almost all the surgical operations can be performed by surgical microscope.

Today Neurosurgery and modern technology constitute the ideally combination for helping patients.

\section{Author details}

'Department of Physical Education and Sports, Aristoteleian Univesity of Thessaloniki, Greece. ${ }^{2}$ Neurosurgical Department, University Hospital AHEPA, Thessaloniki, Greece.

Published: 22 April 2010

Reference

1. Cushing H: The special Geld of neurological surgery. Bull Johns Hopkins Hosp 1905, 16:77-87.

doi:10.1186/1744-859X-9-S1-S89

Cite this article as: Syrmos et al: Historical back training in most important points of neurosurgery. Annals of General Psychiatry 2010 9(Suppl 1):S89.
Submit your next manuscript to BioMed Central and take full advantage of:

- Convenient online submission

- Thorough peer review

- No space constraints or color figure charges

- Immediate publication on acceptance

- Inclusion in PubMed, CAS, Scopus and Google Scholar

- Research which is freely available for redistribution

Submit your manuscript at www.biomedcentral.com/submit 